\title{
EFFECTS OF Teucrium spp. EXTRACTS ON MIGRATORY POTENTIAL AND REDOX STATUS OF HUMAN COLON SW-480 AND BREAST MDA-MB-231 CANCER CELLS
}

\author{
Marko N. Živanović*, Aleksandra Z. Stojanović, Danijela M. Cvetković, \\ Milena G. Milutinović, Milan S. Stanković, Snežana D. Marković \\ Department of Biology and Ecology, Faculty of Science, University of Kragujevac, \\ Radoja Domanovića 12, 34000 Kragujevac, Republic of Serbia \\ *Corresponding author; E-mail: zivanovicm@kg.ac.rs
}

(Received April 11, 2016)

\begin{abstract}
Plant extracts are proved to possess many positive effects in cancer treatment. While many of commonly used therapeutics rely on cytotoxic methodologies, much less are based on positive influence on migrating potential of cancer cells, i.e. on antimetastatic grounds. Here, according to our knowledge, for the first time was investigated influence of Teucrium montanum $\mathrm{L}$. and $T$. polium $\mathrm{L}$. methanolic extracts on migratory potential of colorectal cancer cell line SW-480 and human breast carcinoma MDA-MB-231 cell line. The redox status was evaluated on the basis of concentration of superoxide anion radical $\left(\mathrm{O}_{2}^{-}\right)$, nitrites and reduced glutathione $(\mathrm{GSH})$, determined spectrophotometrically, while migratory potential of cancer cells was followed by real time cell analysis. Our results showed acute increasing of superoxide anion radical, decreasing of nitrites and decreasing of GSH in SW-480 cells. In MDA-MB-231 cells investigated extracts showed no change in GSH level. Also, methanol extract of $T$. montanum in low concentrations decreased cell migration, while $T$. polium showed antimigratory potential in higher concentrations and in treatment periods longer than 12 hours. Investigated Teucrium spp. extracts showed changes in redox status leading to enhancement of oxidative stress. Also, results indicated moderate reducing of migratory potential of tested cancer cells. However, correlation between redox status and antimigratory effects were not observed. According to these findings, the additional investigation of the exact mechanism of antimigratory effect should be performed.
\end{abstract}

KEYWORDS: breast cancer, colon cancer, migration, redox status, Teucrium spp.

\section{INTRODUCTION}

Tumors belong to the greatest challenges among the most common diseases. The processes of formation and spread of tumors in distant locations through the human body (metastases) are studied intensively. In many preclinical studies various chemically synthesized substances are used (JEVTIC et al., 2014; KALINOWSKA-Lis et al., 2008; PETROVIC et al., 2015; SABO et al., 2004), as well as extracts isolated from plant material (Ravelo et al., 2004). Many of these studies are based on toxicity testings, with a focus on in situ selectivity towards a certain type of tumor. However, many studies nowadays are engaged in examining of reducing the possibility of tumors to invade the surrounding tissue, i.e. the decrease of 
metastatic potential. Among many types of tumors, particularly colon and certain types of breast cancer are aggressive, i.e. able to easily metastasize. One of the first steps in the preclinical studies represents research on cancer cell lines. Therefore, we focused our research on the effects of Teucrium spp. methanol extracts in order to investigate the possible oxidative stress and antimigratory effects on colorectal cancer cell line SW-480 and human breast carcinoma MDA-MB-231.

Teucrium spp. plants are commonly used in traditional use since ancient times. Nowadays, Teucrium spp. extracts are proved to be useful for treatment of many physiological conditions, e.g. stomach pain, diabetes (MEHRABANI et al., 2009; VAHIDI et al., 2010), and many others.

It is known that Teucrium montanum and $T$. polium contain many secondary metabolites such as phenolic compounds that could be responsible for their cytotoxic and proapoptotic effects (STANKOVIĆ et al., 2011). T. montanum and Teucrium polium showed in vitro anticancer activity on HCT-116 (STANKOVIĆ et al., 2011) and SW-480 colon cancer cell lines (RAJABALIAN, 2008) as well as on many other cancer cell lines (HAÏDARA et al., 2011; Rajabalian, 2008; Shahat et al., 2016; Stanković et al., 2015). On the other hand, Teucrium polium extract showed to possess antimigratory potential on human prostate cancer cells (KANDOUZ et al., 2010). According to our knowledge, this is the first work that examines the antioxidative/prooxidative effects and antimigratory potential of T. montanum and T. polium on colon cancer SW-480 and breast cancer MDA-MB-231.

\section{MATERIALS AND METHODS}

\section{Chemicals}

Dulbecco`s Modified Eagle Medium (DMEM) and PBS were obtained from GIBCO, Invitrogen, USA. Foetal bovine serum (FBS) and trypsin-EDTA were from PAA (The Cell Culture Company, Pasching, Austria). Dimethyl sulfoxide (DMSO) and nitro blue tetrazolium (NBT) were obtained from SERVA, Heidelberg, Germany. N-1-napthylethylenediamine dihydrochloride was purchased from Fluka chemie GMBH, Buchs, Switzerland. Sulfanilamide and sulphosalicylic acid were purchased from MP Hemija Belgrade, Serbia. 5,5'-dithio-bis(2-nitrobenzoic acid) was purchased from Sigma Chemicals Co., St Louis, MO, USA. All solvents and chemicals were of analytical grade.

\section{Plant material}

T. polium was collected in August 2014 on Stara planina Mountain in Eastern Serbia, while T. montanum was collected in July 2014 on Goč Mountain in Central Serbia. The collected samples were air-dried in darkness, at room temperature.

\section{Preparation of plant extracts}

Prepared plant material $(10 \mathrm{~g})$ consisting of aerial parts of T. polium and T. montanum were transferred to dark-colored flasks. The material was separately soaked in $200 \mathrm{ml}$ of methanol and stored at room temperature. After $24 \mathrm{~h}$, the extracts were filtered through Whatman No. 1 filter paper and the residue was re-extracted with equal volume of solvents. After $48 \mathrm{~h}$, the process was repeated. Combined supernatants were evaporated to dryness under vacuum at $40{ }^{\circ} \mathrm{C}$ using Rotary evaporator. The obtained extracts were kept in sterile sample tubes and stored in a refrigerator at $4{ }^{\circ} \mathrm{C}$. For our investigations we used freshly prepared $1 \mathrm{mg} / \mathrm{ml}$ stock solutions of extracts in $0.1 \%$ DMSO. 


\section{Cell Preparation and Culturing}

The human colon cancer cell line SW-480 and breast cancer cell line MDA-MB-231 were purchased from the American Tissue Culture Collection (Manassas, VA, USA). The cells were propagated in a humidified atmosphere with $5 \% \mathrm{CO}_{2}$ at $37{ }^{\circ} \mathrm{C}$ and maintained in DMEM supplemented with $10 \%$ foetal bovine serum, $100 \mathrm{IU} / \mathrm{ml}$ penicillin and $100 \mu \mathrm{g} / \mathrm{ml}$ streptomycin. The cells were grown in $75 \mathrm{~cm}^{2}$ culture bottles until a confluence of $70-80 \%$ and after a few passages cells were seeded in assay plates. A number of $10^{4}$ cells per well were seeded in a 96-well plate for determination of superoxide anion radical concentration (NBT assay) and nitrites (Griess assay) and $5 \times 10^{4}$ cells per well for determination of reduced glutathione concentration. For migratory potential inhibition assay $2 \times 10^{4}$ cells per well were seeded in RTCA xCelligence well.

\section{Redox Status}

\section{Determination of Superoxide Anion Radical (NBT Assay)}

This method involves estimation of the rate of the reduction of nitrobluetetrazolium (NBT) to nitroblue-formazan in the presence of $\mathrm{O}_{2}{ }^{-}$(AUCLAIR and VOISIN, 1985). The cells were seeded in a 96-well plate. After $24 \mathrm{~h}$ of incubation, the supplementing medium was replaced with $100 \mu \mathrm{l}$ of medium containing extracts at final concentration $(1,10,50$, and $100 \mu \mathrm{g} / \mathrm{ml})$ for 24 and $72 \mathrm{~h}$ treatment duration. Untreated cells served as a control. After treatment period, the assay is performed by adding of $10 \mu \mathrm{l}$ of $5 \mathrm{mg}$ NBT/ml PBS to each well followed with 45 min incubation at $37{ }^{\circ} \mathrm{C}$ in $5 \% \mathrm{CO}_{2}$. To quantify the formazan product, formazan was solubilized in $10 \mu \mathrm{l}$ of DMSO and the resulting color reaction was measured spectrophotometrically at $550 \mathrm{~nm}$ on Micro Plate Reader. The amount of reduced NBT was determined by the change in absorbance, based on molar extinction coefficient for monoformazan $\left(15000 \mathrm{M}^{-1} \mathrm{~cm}^{-1}\right)$. Results were expressed as $\mathrm{nmol} / \mathrm{ml}$.

\section{Nitrite Measurement (Griess Assay)}

The Griess colored reaction represents the spectrophotometric determination of nitrites $-\mathrm{NO}_{2}^{-}$(indicator of the nitric oxide - NO level) (GRIESS, 1879). The Griess reaction is a process of diazotization in which the NO-derived nitrosating agent (e.g., $\mathrm{N}_{2} \mathrm{O}_{3}$ ), generated from the acid-catalyzed formation of nitrous acid from nitrite (or the interaction of NO with oxygen), reacts with sulfanilic acid to produce a diazonium ion that is then coupled to $\mathrm{N}$-(1napthyl)ethylenediamine to form a chromophoric azo product that absorbs strongly at $550 \mathrm{~nm}$. Griess assay is performed at room temperature. All samples were seeded in 96-well microtiter plate, incubated and treated as it was described in NBT assay. After treatment period, $50 \mu 1$ of $0.1 \% \mathrm{~N}$-(1-naphthyl)ethylenediamine and $50 \mu \mathrm{l}$ of $1 \%$ sulfanilamide (solution in $5 \%$ phosphoric acid) were mixed together (the Griess mixture) immediately prior to application to the plate. The absorbance was measured by using a microplate reader following incubation (usually 5-10 $\mathrm{min}$ ). The results were expressed in $\mathrm{nmol} / \mathrm{ml} \mathrm{NO}_{2}^{-}$from a standard curve established in each test, constituted of known molar concentrations of nitrites.

\section{Determination of Reduced Glutathione (GSH)}

Glutathione assay is based on redox reaction of intracellular GSH with Ellmans reagent, 5,5'-dithio-bis(2-nitrobenzoic acid) (DTNB), forming yellow product of 5'-thio-2nitrobenzoic acid (TNB) which strongly absorbs at $405 \mathrm{~nm}$ (BAKER, 1990). Similarly to NBT and Griess assays, cells were seeded in 96-well microtiter plate. The cells were treated with 
$100 \mu \mathrm{l}$ solutions of tested extracts $(0.1,1,10$ and $100 \mu \mathrm{g} / \mathrm{ml})$ for treatment of 24 and $72 \mathrm{~h}$. After treatment period the 96-well plate was centrifuged at $1000 \mathrm{~g}$ for $10 \mathrm{~min}$, and medium was replaced with $100 \mu \mathrm{l}$ ice-cold sulphosalicylic acid and kept on ice for $15 \mathrm{~min}$. The next step is centrifugation of the plates at $1000 \mathrm{~g}$ for $15 \mathrm{~min} .50 \mu \mathrm{l}$ of supernatant from each well were transferred to another plate with subsequent addition of $100 \mu \mathrm{l}$ of reaction mixture (1 mM DTNB in $100 \mathrm{mM}$ phosphate buffer, pH 7.4 with $1 \mathrm{mM}$ EDTA), which was prepared closely before the experiment. The rate of colored reaction was quantified spectrophotometrically on microplate reader following incubation of $5 \mathrm{~min}$. The results were expressed in $\mathrm{nmol} / \mathrm{ml}$ GSH from a standard curve established in each test, constituted of known molar GSH concentrations.

\section{Real Time Cell Analysis}

Analysis of cells in real time includes using of xCELLigence system, which represents integration of microelectronics and cell biology. The mechanism of using of this instrument was detailed summarized previously (MONIRI et al., 2015). It is suitable for monitoring of biological processes of adherent cells (viability, proliferation, cytotoxicity, migration). It uses special microtiter plates equipped with gold micro electrodes which in turn measure electrical impedance of the cell population preceding the quantitative information regarding the cell status in real time. Every viable cell that is attached to the gold electrode contributes to the signal of impedance. The more living cells, the higher the impedance.

\section{Determination of Cell Migration}

Before experiment it is needed to propagate cells in FBS-free medium for $24 \mathrm{~h}$. Then, $30 \mu \mathrm{l}$ solution of cells were seeded in 16 well CIM-plate in the upper chamber. In lower chamber it was added $160 \mu \mathrm{l}$ DMEM supplied with $20 \%$ FBS as attractant. T. montanum and T. polium extracts were added prior to the upper chamber to obtain necessary concentration $(1,10$ and $50 \mu \mathrm{g} / \mathrm{ml}$ ). As result in this assay we followed CI (cell index) for $24 \mathrm{~h}$, with measuring frequency of 15 minutes.

\section{Statistics}

All experimental data were expressed as mean \pm standard error (SE). Cell index (CI) for real-time migration estimation $(n=3)$ was calculated automatically by the RTCA Software Package 1.2 of the RTCA system. Normalizations were performed using the RTCA Software Package 1.2. Biological activity assays are performed in triplicate for each dose. Statistical significance was determined using the one-way ANOVA test for multiple comparisons. A p value $<0.05$ was considered as significant. The magnitude of correlation between variables was done using SPSS (Chicago, IL) statistical software package (SPSS for Windows, version 17, 2008).

\section{RESULTS}

\section{Redox Status}

\section{Concentration of Superoxide Anion Radical $\left(\mathrm{O}_{2}{ }^{-}\right)$}

Among all reactive oxygen species superoxide anion radical is one of the most important radical involved in many processes in human cells, because of its content and high reactivity. Superoxide anion radical is an important indicator of ROS level (Hancock, 2001) 
and is a key player in oxidative stress processes. In this paper we presented results regarding the level of superoxide on SW-480 and MDA-MB-231 cells (Table 1). Results on SW-480 cells showed that investigated extracts $24 \mathrm{~h}$ from treatment increased $\mathrm{O}_{2}{ }^{--}$concentration, while after $72 \mathrm{~h}$ from treatment extracts induced decreasing of $\mathrm{O}_{2}{ }^{-}$level. On MDA-MB-231 cells methanolic extract of T. montanum induced increasing of $\mathrm{O}_{2}{ }^{-} 24 \mathrm{~h}$ from treatment, while after $72 \mathrm{~h}$ concentrations of 1 and $100 \mu \mathrm{g} / \mathrm{ml}$ decreased, and 10 and $50 \mu \mathrm{g} / \mathrm{ml}$ increased $\mathrm{O}_{2}{ }^{--}$level. Higher concentration of $T$. polium on MDA-MB-231 after $24 \mathrm{~h}$ from treatment showed prooxidative character, i.e. increased $\mathrm{O}_{2}{ }^{-}$level, while $72 \mathrm{~h}$ from treatment only concentration of $10 \mu \mathrm{g} / \mathrm{ml}$ showed prooxidative character.

Table 1. Effects of methanolic extracts of Teucrium montanum and T. polium on SW-480 and MDA-MB-231 cell lines, expressed as the $\mathrm{O}_{2}{ }^{-}$concentration after $24 \mathrm{~h}$ and $72 \mathrm{~h}$ of exposure.

${ }^{*} \mathrm{p}<0.05$ as compared to the control cells.

\begin{tabular}{|c|c|c|c|c|}
\hline \multirow{3}{*}{$\begin{array}{c}\text { Concentration } \\
\mu \mathrm{g} / \mathrm{ml}\end{array}$} & \multicolumn{4}{|c|}{ Superoxide anion radical, $\mathrm{O}_{2}{ }^{\circ-}(\mathrm{nmol} / \mathrm{ml})$} \\
\hline & \multicolumn{2}{|c|}{$\mathrm{SW}-480$} & \multicolumn{2}{|c|}{ MDA-MB-231 } \\
\hline & T. montanum & T. polium & T. montanum & T.polium \\
\hline \multicolumn{5}{|c|}{$24 \mathrm{~h}$} \\
\hline $\mathbf{0}$ & $26.81 \pm 0.55$ & $26.81 \pm 0.55$ & $27.34 \pm 0.27$ & $27.34 \pm 0.27$ \\
\hline 1 & $25.95 \pm 0.88$ & $24.60 \pm 0.50$ & $28.61 \pm 0.45^{*}$ & $26.92 \pm 0.16^{*}$ \\
\hline 10 & $28.75 \pm 1.00$ & $29.79 \pm 2.02$ & $27.29 \pm 0.48$ & $26.81 \pm 0.22$ \\
\hline 50 & $27.44 \pm 0.35$ & $32.76 \pm 3.20 *$ & $28.51 \pm 0.59 *$ & $37.21 \pm 2.17 *$ \\
\hline 100 & $28.51 \pm 0.45^{*}$ & $29.13 \pm 3.61$ & $27.51 \pm 0.33$ & $30.55 \pm 0.62$ \\
\hline \multicolumn{5}{|c|}{$72 \mathrm{~h}$} \\
\hline $\mathbf{0}$ & $28.35 \pm 1.13$ & $28.35 \pm 1.13$ & $25.08 \pm 0.95$ & $25.08 \pm 0.95$ \\
\hline 1 & $28.12 \pm 1.88$ & $24.44 \pm 0.96 *$ & $22.44 \pm 0.64 *$ & $25.07 \pm 1.21$ \\
\hline 10 & $27.27 \pm 3.24$ & $24.77 \pm 0.65^{*}$ & $28.19 \pm 1.92 *$ & $35.75 \pm 2.75 *$ \\
\hline 50 & $27.69 \pm 1.22$ & $24.40 \pm 0.22 *$ & $26.64 \pm 0.97$ & $25.92 \pm 1.41$ \\
\hline 100 & $23.57 \pm 0.53^{*}$ & $26.47 \pm 1.32$ & $23.83 \pm 0.82$ & $26.75 \pm 0.70$ \\
\hline
\end{tabular}

\section{Concentration of Nitrites $\left(\mathrm{NO}_{2}^{-}\right)$}

Concentration of nitrites indicates quantity of nitrosonium ions $\left(\mathrm{NO}^{+}\right)$in anaerobic conditions. In water, the final product of aerobic phase reaction between nitrogen oxide (NO) and $\mathrm{O}_{2}$ is nitrogen dioxide $\left(\mathrm{NO}_{2}\right)$, which quickly combines with excess of $\mathrm{NO}$, forming nitrogen trioxide $\left(\mathrm{N}_{2} \mathrm{O}_{3}\right)$ that is hydrolyzed to nitrites. So, nitrite concentration may indicate level of NO and other reactive nitrogen species in cells (LANCASTER, 2006). Nitrite concentration measurement results are depicted in Table 2. Results obtained on SW-480 cells revealed that $T$. montanum extract significantly decreases nitrites, when compared to control cells 24 and $72 \mathrm{~h}$ from treatment. Extract of $T$. polium also significantly reduced nitrite level except in concentration of $100 \mu \mathrm{g} / \mathrm{ml} 72 \mathrm{~h}$ from treatment. On MDA-MB-231 cells 24 from treatment it was observed that high concentrations of $T$. montanum extract significantly increased nitrites, while after $72 \mathrm{~h} T$. montanum extract showed no significant effect on nitrite level. Methanolic extract of $T$. polium in concentration of $50 \mu \mathrm{g} / \mathrm{ml}$ significantly decreased nitrites $24 \mathrm{~h}$ from treatment, while after $72 \mathrm{~h}$ high concentrations increased nitrite level.

\section{Concentration of Reduced Glutathione (GSH)}

Glutathione, GSH (c-Glu-Cys-Gly) is a tripeptide presented in low concentrations in cells with strong antioxidative function (Nordberg and Arner, 2001.). Table 3 represents the effects 
of investigated extracts on GSH level in SW-480 and MDA-MB-231 cells. On SW-480 cells T. montanum and T. polium extracts predominantly decreased GSH concentration. The effect of tested extracts was quite different on MDA-MB-231 cells, when compared to SW-480 cells. T. montanum and T. polium extracts exerted no effect on GSH changing.

Table 2. Effects of methanolic extracts of Teucrium montanum and T. polium on SW-480 and MDA-MB-231 cell lines, expressed as the $\mathrm{NO}_{2}^{-}$concentration after $24 \mathrm{~h}$ and $72 \mathrm{~h}$ of exposure. $* \mathrm{p}<0.05$ as compared to the control cells.

\begin{tabular}{|c|c|c|c|c|}
\hline \multirow{3}{*}{$\begin{array}{c}\text { Concentration } \\
\mu \mathrm{g} / \mathrm{ml}\end{array}$} & \multicolumn{4}{|c|}{ Nitrites, $\mathrm{NO}_{2}^{-}(\mathrm{nmol} / \mathrm{ml})$} \\
\hline & \multicolumn{2}{|c|}{ SW-480 } & \multicolumn{2}{|c|}{ MDA-MB-231 } \\
\hline & T. montanum & T. polium & T. montanum & T.polium \\
\hline \multicolumn{5}{|c|}{$24 \mathrm{~h}$} \\
\hline $\mathbf{0}$ & $12.85 \pm 0.75$ & $12.85 \pm 0.75$ & $14.96 \pm 0.29$ & $14.96 \pm 0.29$ \\
\hline 1 & $8.28 \pm 0.20 *$ & $6.40 \pm 0.40^{*}$ & $14.32 \pm 0.46$ & $14.01 \pm 0.17$ \\
\hline 10 & $7.89 \pm 0.29 *$ & $8.04 \pm 0.37 *$ & $14.04 \pm 0.31$ & $15.17 \pm 0.40$ \\
\hline 50 & $8.62 \pm 0.32 *$ & $10.40 \pm 0.67$ & $16.52 \pm 0.87 *$ & $13.53 \pm 0.45^{*}$ \\
\hline 100 & $8.13 \pm 0.63 *$ & $12.81 \pm 1.13$ & $16.68 \pm 0.74 *$ & $15.78 \pm 0.36$ \\
\hline \multicolumn{5}{|c|}{$72 \mathrm{~h}$} \\
\hline $\mathbf{0}$ & $16.81 \pm 0.68$ & $16.81 \pm 0.68$ & $11.49 \pm 0.53$ & $11.49 \pm 0.53$ \\
\hline 1 & $13.42 \pm 3.04$ & $12.66 \pm 0.89$ & $10.22 \pm 0.20$ & $10.85 \pm 0.44$ \\
\hline 10 & $11.29 \pm 0.94 *$ & $14.18 \pm 1.84$ & $9.76 \pm 0.25$ & $10.33 \pm 0.49$ \\
\hline 50 & $11.24 \pm 0.90 *$ & $16.21 \pm 2.30$ & $9.69 \pm 0.30$ & $12.04 \pm 0.53$ \\
\hline 100 & $11.55 \pm 1.07 *$ & $24.23 \pm 5.06 *$ & $10.47 \pm 0.36$ & $18.44 \pm 2.75 *$ \\
\hline
\end{tabular}

Table 3. Effects of methanolic extracts of Teucrium montanum and T. polium on SW-480 and MDAMB-231 cell lines, expressed as the GSH concentration after $24 \mathrm{~h}$ and $72 \mathrm{~h}$ of exposure.

$* \mathrm{p}<0.05$ as compared to the control cells.

\begin{tabular}{|c|c|c|c|c|}
\hline \multirow{3}{*}{$\begin{array}{c}\text { Concentration } \\
\mu \mathrm{g} / \mathrm{ml}\end{array}$} & \multicolumn{4}{|c|}{ Glutathione, GSH (nmol/ml) } \\
\hline & \multicolumn{2}{|c|}{ SW-480 } & \multicolumn{2}{|c|}{ MDA-MB-231 } \\
\hline & T. montanum & T.polium & T. montanum & T. polium \\
\hline \multicolumn{5}{|c|}{$24 \mathrm{~h}$} \\
\hline $\mathbf{0}$ & $15.87 \pm 0.23$ & $15.87 \pm 0.23$ & $13.17 \pm 0.35$ & $13.17 \pm 0.35$ \\
\hline 1 & $15.33 \pm 0.14$ & $14.57 \pm 0.37 *$ & $14.31 \pm 0.47$ & $11.94 \pm 0.51$ \\
\hline 10 & $15.29 \pm 0.38$ & $14.92 \pm 0.21 *$ & $12.48 \pm 0.46$ & $14.04 \pm 0.90$ \\
\hline 50 & $15.31 \pm 0.46$ & $13.91 \pm 0.27 *$ & $12.45 \pm 0.37$ & $13.69 \pm 0.27$ \\
\hline 100 & $13.87 \pm 0.39 *$ & $15.34 \pm 0.54$ & $12.89 \pm 0.39$ & $13.06 \pm 0.42$ \\
\hline \multicolumn{5}{|c|}{$72 \mathrm{~h}$} \\
\hline $\mathbf{0}$ & $15.21 \pm 0.27$ & $15.21 \pm 0.27$ & $15.80 \pm 0.34$ & $15.80 \pm 0.34$ \\
\hline 1 & $13.79 \pm 0.35^{*}$ & $13.04 \pm 0.21 *$ & $16.06 \pm 0.55$ & $16.04 \pm 0.24$ \\
\hline 10 & $14.42 \pm 0.20$ & $15.19 \pm 0.31$ & $15.41 \pm 0.45$ & $17.13 \pm 1.00$ \\
\hline 50 & $13.30 \pm 0.22 *$ & $13.73 \pm 0.29 *$ & $15.46 \pm 0.35$ & $14.81 \pm 0.30$ \\
\hline 100 & $14.58 \pm 0.47$ & $13.81 \pm 0.45 *$ & $15.36 \pm 0.34$ & $13.93 \pm 0.38^{*}$ \\
\hline
\end{tabular}

\section{Real Time Cell Analysis and Cell Migration}

Effects of T. montanum and T. polium extracts on migratory potential of SW-480 and MDA-MB-231 cells were monitored and depicted in Figure 1 and Table 4. Presented results 
on SW-480 cells revealed that low concentration $(1 \mu \mathrm{g} / \mathrm{ml})$ of $T$. montanum extract reduced, while concentrations 10 and $50 \mu \mathrm{g} / \mathrm{ml}$ enhanced cell migration (Figure 1). On the other hand T. polium extract showed significant effect on cell migration reduction in all investigated concentrations. Investigation of T. montanum extract on MDA-MB-231 cells revealed that concentrations $10 \mu \mathrm{g} / \mathrm{ml}$ decreased migratory potential, while 1 and $50 \mu \mathrm{g} / \mathrm{ml}$ after $12 \mathrm{~h}$ from treatment enhanced cell migration. T. polium influenced MDA-MB-231 cell migration in dose and time dependent manner. Concentrations 10 and $50 \mu \mathrm{g} / \mathrm{ml}$ in period from 6 to 12 hours enhanced cell migration, while 18 and $24 \mathrm{~h}$ from treatment these concentrations reduced cell migration. On the other hand $1 \mu \mathrm{g} / \mathrm{ml}$ showed promigratory effect during the whole period of treatment.
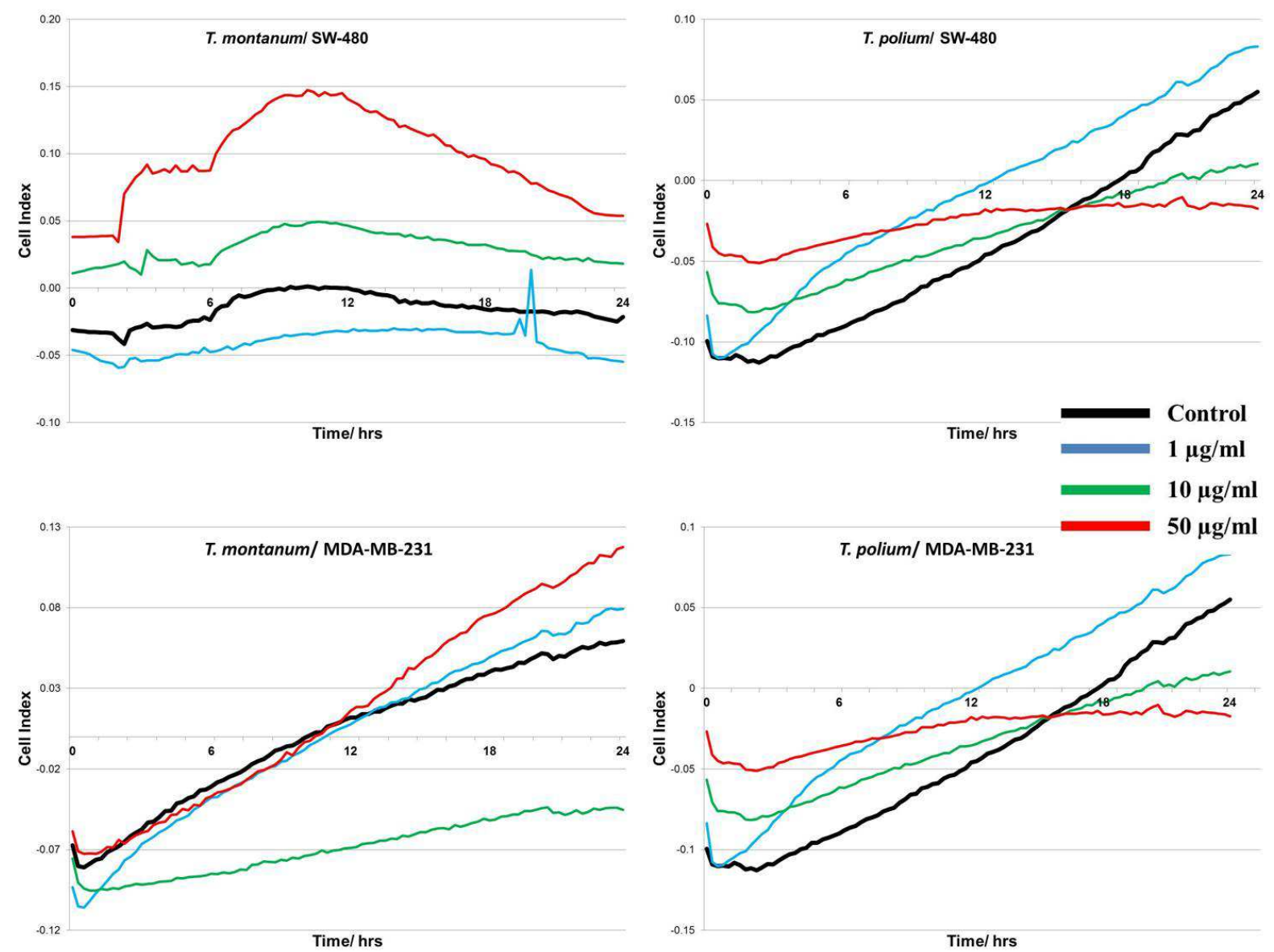

Figure 1. Effects of Teucrium montanum and T. polium extracts on migration of SW-480 and MDA-MB-231 cell lines.

\section{DISCUSSION}

Area of Republic of Serbia is characterized by a very diverse flora with the large number of plants that possess proven medicinal effect (SARIC, 1989.). However, there is not enough investigations on the subject of study of their antitumor effects. Plants of the Teucrium genus contain phenolic compounds with strong biological activity (STANKOVIĆ et al., 2011). Teucrium genus plants are commonly used in the treatment of conjunctivitis, abscess, gout, respiratory diseases, digestive tract and many others (STANKOVIĆ et al., 2011). In this study we represent results of the effects of methanolic extracts of T. montanum, which 
is sampled on the serpentine, as well as T. polium sampled on the limestone substrate. It was studied influence of extracts on redox status, and migration of SW-480 and MDA-MB-231 cell lines.

Table 4. Effects of T. montanum and T. polium extracts on migration of SW-480 and MDA-MB-231 cell lines $6 \mathrm{~h}, 12 \mathrm{~h}, 18 \mathrm{~h}$ and $24 \mathrm{~h}$ from treatment.

\begin{tabular}{|c|c|c|c|c|c|c|c|c|}
\hline \multirow{3}{*}{$\begin{array}{c}\text { Concentration } \\
\mu \mathrm{g} / \mathrm{ml}\end{array}$} & \multicolumn{8}{|c|}{ Cell index } \\
\hline & \multicolumn{4}{|c|}{ Teucrium montanum } & \multicolumn{4}{|c|}{ Teucrium montanum } \\
\hline & $6 \mathrm{~h}$ & $12 \mathrm{~h}$ & $18 \mathrm{~h}$ & $24 \mathrm{~h}$ & $6 \mathrm{~h}$ & $12 \mathrm{~h}$ & $18 \mathrm{~h}$ & $24 \mathrm{~h}$ \\
\hline & \multicolumn{8}{|c|}{ SW -480 cell line migration } \\
\hline $\mathbf{0}$ & -0.02 & 0.00 & -0.02 & -0.02 & 0.02 & 0.02 & 0.01 & 0.00 \\
\hline $\mathbf{1}$ & -0.05 & -0.03 & -0.03 & -0.05 & -0.01 & -0.01 & -0.02 & -0.02 \\
\hline 10 & 0.02 & 0.05 & 0.03 & 0.02 & -0.04 & -0.06 & -0.08 & -0.10 \\
\hline \multirow[t]{2}{*}{50} & 0.09 & 0.14 & 0.10 & 0.05 & 0.00 & -0.02 & -0.05 & -0.07 \\
\hline & \multicolumn{8}{|c|}{ MDA-MB-231 cell line migration } \\
\hline $\mathbf{0}$ & -0.03 & 0.01 & 0.04 & 0.06 & -0.09 & -0.05 & 0.00 & 0.05 \\
\hline $\mathbf{1}$ & -0.04 & 0.01 & 0.05 & 0.08 & -0.04 & 0.00 & 0.04 & 0.08 \\
\hline 10 & -0.08 & -0.07 & -0.05 & -0.04 & -0.06 & -0.04 & -0.01 & 0.01 \\
\hline 50 & -0.04 & 0.02 & 0.08 & 0.12 & -0.03 & -0.02 & -0.02 & -0.02 \\
\hline
\end{tabular}

T. montanum and T. polium exerted some differences in their biological action. The possible cause of the difference in efficiency and biological activity are differences of their phenolic composition. Numerous factors influence the differences in the concentration of phenolic compounds in plants, such as plant maturity, time of sampling, environmental factors, preparation and storage of samples. Environmental factors include the composition of the soil, climate, exposure to the sunlight that has the greatest impact on the composition of flavonoids, as one of the most active group of phenolic compounds in plant material sampled (MACHEIX et al., 1990).

Redox regulation has an important role in cell survival, apoptosis and regulation of various signaling pathways in the cell. Changes in ROS/RNS production could modify signal pathways in the cell by direct modification of biomolecules, especially proteins (ENGLAND and COTTER, 2005). Also, level of regulation of the expression of the protein ROS/RNS could change the protein function by regulation of expression of activity of transcription factors, such as NF-kB, AP-1 and HIF-1 $\alpha$ (TURPAEV, 2002; ACKER et al., 2006; OZBEN, 2007; MATES et al., 2012) or by protein posttranslatory modifications (HENEBERG and DRABER, 2005). The concentration of superoxide anion radical, as one of the most potent reactive oxygen species in cell is an indicator of oxidative stress. The results showed that the extracts of both tested plants after $24 \mathrm{~h}$ induced an increase of the concentration of $\mathrm{O}_{2}{ }^{--}$in SW-480 cells, while after $72 \mathrm{~h} \mathrm{O}_{2}{ }^{-}$decreased, which indicates us that extracts possessed acute prooxidative effect. With the extension of time of treatment, the plants showed the protective effect, i.e. antioxidative properties mainly due to prolonged antioxidant activity of protective system in cells and adaptation of the cells to oxidative stress. Results for MDA-MB-231 cells show quiet different effect. T. montanum extract induced oxidative stress after $24 \mathrm{~h}$. After $72 \mathrm{~h}$ concentrations 1 and $100 \mu \mathrm{g} / \mathrm{ml}$ induced antioxidative effect, while concentrations 10 and 50 $\mu \mathrm{g} / \mathrm{ml}$ exerted prooxidative effect. Methanolic extract of $T$. polium in high concentrations after $24 \mathrm{~h}$ act as prooxidant, while after $72 \mathrm{~h}$ only at a concentration of $10 \mu \mathrm{g} / \mathrm{ml}$ exerts prooxidative effect. The results show that extracts of these herbs act as prooxidants and antioxidants on tested cell lines, which is probably due to the chemical structure and properties of phenols which react at the same time as reducing and oxidizing agents, depending on the environment in which they are located. 
The chemical mediator, NO molecule, with very important activity in the body (MONCADA and HigGS, 1993) is synthesized by nitrite oxide synthase. Treatment of investigated plant extracts lead to a decrease in nitrite concentrations in SW-480 and MDAMB-231 cells. Results presented in this study confirm the findings of other authors (JEONG and JEONG, 2010; TAE and KIM, 2012) suggesting that some components in extracts (usually a phenolic compounds) are associated with intracellular components and molecules involved in the production of $\mathrm{NO}$, leading to inhibition of this molecule by decreasing in the expression of inducible nitric oxide synthase (iNOS). Extracts with the presence of quercetin, such as the extract of the plant $T$. polium, reduce the production of NO by the cell culture of astrocytes (SOLIMAN and MAZZIO, 1998) or by the inhibition of iNOS protein. Nitric oxide has a short half-life in environments rich in $\mathrm{O}_{2}{ }^{-}$which has a great affinity towards $\mathrm{NO}$ forming peroxynitrites (WINK and MITCHELL, 1998), which, consequently, can reduce the concentration of NO in the cells treated with the extract of plants. According to STANKOVIĆ et al. (2011) T. montanum contain higher content of total phenolic compounds than T. polium. Considering our results, T. montanum mainly induced lesser production of superoxide and nitrites than $T$. polium, which could be related to the content of total phenolic compounds, which mainly act as antioxidants.

Oxidative stress present in cells mainly includes changes in the level GSH system, as the first line of antioxidant defense. Our results show a significant reduction in the concentration of GSH in SW-480 cells under the influence of both plant extracts. MDA-MB231 cells react a little differently and investigated extracts influenced no change in GSH production.

Migration and invasion of cancer cells represent the initial step in metastasis of cancer, which is the primary cause of death from cancer. The metastasis of primary tumor cells migrates into the surrounding tissue and enter the blood circulation in order to form secondary tumors (BACAC and STAMENKOVIC, 2008). Estimation of the effects of extracts on migratory potential of SW-480 and MDA-MB-231 cells is determined in real time by RTCA xCELLigence system. The results show that methanol extract of $T$. montanum in low concentrations show antimigratory effect $(1 \mu \mathrm{g} / \mathrm{ml}$ on SW-480, and $10 \mu \mathrm{g} / \mathrm{ml}$ on MDA-MB231 cells), while other treatment concentrations act promigratory. On the other hand, $T$. polium extract significantly decreased migratory potential of SW-480 and MDA-MB-231 cells in higher concentrations and in treatment periods longer than 12 hours. Our results do not allow us to correlate redox status with influence on migratory potential of cells. Even though some studies investigated the effect of ROS on cell migration (ALEXANDROVA et al., 2006; FINI et al., 2008; NISHIKAWA et al., 2008), our results indicate that investigated Teucrium extracts influence the cell migration through mechanisms possible independent from redox status. KANDOUZ et al. (2010) showed that Teucrium polium plant extract inhibited cell invasion of human prostate cancer cells via the restoration of the Ecadherin/catenin complex. Such findings refer us to investigate mechanisms alternative to redox status related influence. From the data discussed in this article, and from our measured parameters, Teucrium plant extracts showed cytotoxic, proapoptotic and antimigratory potential and they should be considered for serious investigation, especially in elucidating of the effects on antimetastatic potential.

\section{Acknowledgment}

This work was supported by the Ministry of Science and Technological Development of the Republic of Serbia (project III41010). 


\section{References:}

[1] ACKER, T., FANDREY, J., ACKER, H. (2006): The good, the bad and the ugly in oxygensensing: ROS, cytochromes and prolyl-hydroxylases. Cardiovascular Research 71 (2): 195-207.

[2] Alexandrova, A.Y., Kopnin, P.B., Vasiliev, J.M., Kopnin, B.P. (2006): ROS upregulation mediates Ras-induced changes of cell morphology and motility. Experimental Cell Research 312 (11): 2066-2073.

[3] AuClair, C., Voisin, E. (1985): Nitroblue tetrazolium reduction. In: GreENwaLd, R.A. (ed.) Handbook of methods for oxygen radical research, CRC Press, Boka Raton.

[4] Bacac, M., Stamenkovic, I. (2008): Metastatic cancer cell. Annual Review of Pathology 3: 221-247.

[5] BaKer, M.A., Cerniglia, G.J., Zaman, A. (1990): Microtiter plate assay for the measurement of glutathione and glutathione disulfide in large numbers of biological samples. Analytical Biochemistry 190: 360-365.

[6] England, K., CotTer, T.G. (2005): Direct oxidative modification of signaling proteins in mammalian cells and their effects on apoptosis. Redox Report 10: 237-245.

[7] Fini, M.A., Orchard-Webb, D., Kosmider, B., Amon, J.D., Kelland, R., Shibao, G. (2008): Migratory activity of human breast cancer cells is modulated by differential expression of xanthine oxidoreductase. Journal of Cellular Biochemistry 105 (4):100826.

[8] GRIESS, P. (1879): Bemerkungen zu der Abhandlung der HH. Weselky und Benedikt Ueber einige Azoverbindungen. Berichte der Deutschen Chemischen Gesellschaft 12: 426-428.

[9] Haïdara K, AlachKar A, Al Moustafa A. (2011): Teucrium polium plant extract provokes significant cell death in human lung cancer cells. Health 3 (6): 366-369.

[10] HANCOCK, J.T., DesikAN, R., NeILl, S.J. (2001): Role of reactive oxygen species in cell signalling pathways. Biochemical Society Transactions 29 (2):345-50.

[11] Heneberg, P., Draber, P. (2005): Regulation of cys-based protein tyrosine phosphatases via reactive oxygen and nitrogen species in mast cells and basophils. Current Medicinal Chemistry 12: 1859-1871.

[12] JeONG, J.B., JeONG, H.J. (2010): Rheosmin, a naturally occurring phenolic compound inhibits LPS-induced iNOS and COX-2 expression in RAW264.7 cells by blocking NFkappaB activation pathway. Food and Chemical Toxicology 48(8-9):2148-53.

[13] Jevtic, V.V., Radic, G.P., Seklic, D., Zivanovic, M., Markovic, S., Trifunovic, S.R. (2014): Part XVI - Stereospecific ligands and their complexes. Synthesis, characterization and in vitro antiproliferative activity of new platinum(IV) complexes with some $\mathrm{O}, \mathrm{O}^{`}$-dialkyl esters of $(\mathrm{S}, \mathrm{S})$-ethylenediamine-N,N`di-2-propanoic acid against breast cancer. Macedonian Journal of Chemistry and Chemical Engineering $\mathbf{3 3}$ (1): 53-58.

[14] Kalinowska-Lis, U., Ochocki, J., Matlawska-Wasowska, K. (2008): Trans geometry in platinum antitumor complexes. Coordination Chemistry Reviews 252 (1214): $1328-45$. 
[15] Kandouz, M., Alachkar, A., Zhang, L., Dekhil, H., Chehna, F., Yasmeen, A., Al MoustafA, A.E. (2010): Teucrium polium plant extract inhibits cell invasion and motility of human prostate cancer cells via the restoration of the E-cadherin/catenin complex. Journal of Ethnopharmacology 129 (3): 410-5,

DOI: 10.1016/j.jep.2009.10.035.

[16] LANCASTER, J.R. (2006): Nitroxidative, nitrosative, and nitrative stress: kinetic predictions of reactive nitrogen species chemistry under biological conditions. Chemical Research in Toxicology 19 (9): 1160-74.

[17] MacheiX, J., Fleuriet, A., Billot, J. (1990): Fruit phenolics. FL:CRC Press, Boca Raton.

[18] Mates, J.M., Segura, J.A., Alonso, F.J., Marquez, J. (2012): Oxidative stress in apoptosis and cancer: an update. Archives of Toxicology 86 (11): 1649-1665.

[19] Mehrabani, D., Rezaee, A., Azarpira, N., Fattahi, M.R., Amini, M., Tanideh, N., PAnJehshahin, M.R., SABeri-FIROUZI, M. (2009): The healing effects of Teucrium polium in the repair of indomethacin-induced gastric ulcer in rats. Saudi Medical Journal 30 (4): 494-9.

[20] Moncada, S., Higgs, A. (1993): The L-arginine-nitric oxide pathway. New England Journal of Medicine 329: 2002-2012.

[21] Moniri, M.R., Young, A., Reinheimer, K., Rayat, J., Dai, LJ., Warnock, G.L. (2015): Dynamic assessment of cell viability, proliferation and migration using real time cell analyzer system (RTCA). Cytotechnology 67 (2): 379-386

[22] Nishikawa, M. (2008): Reactive oxygen species in tumor metastasis. Cancer Letters 266 (1):53-9.

[23] Nordberg, J., Arner, E.S. (2001): Reactive oxygen species, antioxidants, and the mammalian thioredoxin system. Free Radical Biology \& Medicine 31: 1287-1312.

[24] OzBEN, T. (2007): Oxidative stress and apoptosis: impact on cancer therapy. Journal of Pharmaceutical Sciences 96: 2181-2196.

[25] Petrovic, V.P., Zivanovic, M.N., Simijonovic, D., Dorovic, J., Petrovic, Z.D., MARKovic, S.D. (2015): Chelate N,O-palladium(ii) complexes: synthesis, characterization and biological activity. Royal Society of Chemistry Advances 5 (105): 86274-81.

[26] Rajabalian, S. (2008): Methanolic extract of Teucrium polium L. potentiates the cytotoxic and apoptotic effects of anticancer drugs of vincristine, vinblastine and doxorubicin against a panel of cancerous cell lines. Experimental Oncology 30 (2): 1338.

[27] Ravelo, A.G., Estévez-Braun, A., Chávez-Orellana, H., Pérez-Sacau, E., MesaSIVERIO, D. (2004): Recent studies on natural products as anticancer agents. Current Topics in Medicinal Chemistry 4 (2): 241-265.

[28] Sabo, T.J., Kaluderovic, G.N., Grguric-Sipka, S.R., Heinemann, F.W., Trifunovic, S.R. (2004): Complex compounds of platinum(IV) and O,O`-dialkyl-ethylenediamineN,N`-di-3-propanoate ligands. A structural evidence for geometry of hydrolytic product of some esters. Inorganic Chemistry Communications 7 (2): 241-4

[29] SARIC, M.R. (1989): Lekovite biljke SR Srbije, SANU, Beograd, Srbija. 
[30] Shahat, A., Alsaid, M., Kotob, S., Husseiny, H., El-Ghamdi, A., Ahmed, H. (2016): Biochemical and histological evidences for the antitumor potential of Teucrium Oliverianum and Rhazya stricta in chemically-induced hepatocellular carcinoma. African Journal of Traditional, Complementary and Alternative Medicines 13 (1): $62-70$

[31] Soliman, K.F., MAZZIO, E.A. (1998): In vitro attenuation of nitric oxide production in C6 astrocyte cell culture by various dietary compounds. Proceedings of the Society for Experimental Biology and Medicine 218 (4): 390-397.

[32] Stanković, M., ĆurČić, M., ŽižIĆ, J., Topuzović, M., Solujić, S., Marković, S. (2011): Teucrium plant species as natural sources of novel anticancer compouds: antiproliferative, proapoptotic and antioxidant properties. International Journal of Molecular Sciences 12 (7): 4190-4205.

[33] Stanković, M., Mitrović, T., Matić, I., Topuzović, M., Stamenković, S. (2015): New Values of Teucrium species: in Vitro Study of Cytotoxic Activities of Secondary Metabolites. Notulae Botanicae Horti Agrobotanici 43 (1): 41-46

[34] TAE, K., KIM, J. (2012): Inhibition of iNOS and DNA Oxidation by Methanol Extract of Schizonepeta tenuifolia. Tropical Journal of Pharmaceutical Research 11: 397-404.

[35] TURPAEV, K.T. (2002): Reactive oxygen species and regulation of gene expression. Biochemistry 67: 281-292.

[36] Vahidi, A.R., Dashti-Rahmatabadi, M.H., Bagheri, S.M. (2010): The effect of Teucrium polium boiled extract in diabetic rats. Iranian Journal of Diabetes and Obesity 2 (2): 27-32

[37] Wink, D.A, Mitchell, J.B. (1998): Chemical biology of nitric oxide: insights into regulatory, cytotoxic, and cytoprotective mechanisms of nitric oxide. Free Radical Biology \& Medicine 25: 434-456. 